\title{
The Evolution of Economic History since 1950: From Cliometrics to Cliodynamics
}

\author{
La evolución de la historia económica desde 1950: \\ de cliometría hasta cliodinámica
}

\author{
Javier Mejía \\ Universidad de los Andes* \\ http://orcid.org/0000-0003-4815-8942 \\ j.mejia10@uniandes.edu.co
}

Fecha de recepción: 10 de junio de 2015 Fecha de aceptación: 20 de octubre de 2015

Sugerencia de citación: Mejia, J. (2015). The Evolution of Economic History since 1950: From Cliometrics to Cliodynamics. tiempo\&economía, 2(2), 79-103

\section{Abstract}

This paper analyzes the evolution of economic history in the last 65 years. It argues that economic history has followed a path that goes from the strictly use of standard economics applied to economic past (i.e. cliometrics), to a general formal reflection of social history based on more flexible tools (i.e. cliodynamics). While cliometrics was a paradigm based on neoclassical theory and econometric methods, cliodynamics is a research agenda founded in non-neoclassical theoretical frameworks and quantitative methods not based on statistical inference. In that sense, the paper supports the idea that economic history has maintained its relevance in economics literature, despite the decay of particular traditions in the field.

Keywords: cliodynamics, cliometrics, Economic history.

JEL Codes: B2, B4, N01, O1

* The author is grateful to Andrés Álvarez for his valuable comments. 


\section{Resumen}

Este artículo analiza la evolución de la historia económica en los últimos 65 años. Se argumenta que la historia económica ha pasado de un paradigma caracterizado por aplicar la economía estándar al pasado (cliometría) a reflexiones más generales sobre la historia social, basadas en herramientas más flexibles (cliodinámica). Mientras la cliometríra se basaba en la teoría neoclásica y los métodos econométricos, la cliodinámica parte de marcos teóricos no neoclásicos y métodos diferentes a la inferencia estadística. Con esto, este artículo respalda la idea de que la historia económica, a pesar de la decadencia de tradiciones particulares dentro de ella, ha mantenido su relevancia en economía.

Palabras clave: cliodinámica, cliometría, historia económica.

Códigos JEL: B2, B4, N01, 01 


\section{Introduction}

There are plenty of studies reviewing the evolution of economic history. Almost all of them focus in the emergence and decadence of cliometrics. ${ }^{1}$ Nevertheless, that evolution followed a more complex path, full of divergences and interactions with other disciplines and approaches. This paper presents and analyzes that path, showing how economic history has evolved over the last 65 years.

This paper does not pretend to be a survey on the field, it rather pretends to propose a reflection based on the seminal literature. Moreover, its attention focuses on the economic history within mainstream economics. Therefore, it lays aside the evolution of other intellectual traditions that were interested in economic history and were important in other contexts. For instance, we mention just obliquely Annales, Marxist and Structuralist schools. Those were traditions highly concerned on economic history and were quite influential in several regions, but remained peripheral for mainstream economics.

The paper tries to show that, against what many authors suggest, ${ }^{2}$ economic history never passed through a decline stage. Its path is better defined as the succession of four major steps. The first one was an initial scientific revolution that generated the emergence of cliometrics. Then, cliometrics became the dominant paradigm. In a third stage, cliometrics collapsed as paradigm, and different branches of economic history emerged, some of which would reach mainstream discussions in economics. Finally, nowadays all those branches seem to converge into a new paradigm, namely cliodynamics (see diagram 1).

Diagram 1. The path of economic history. 1950-2015.

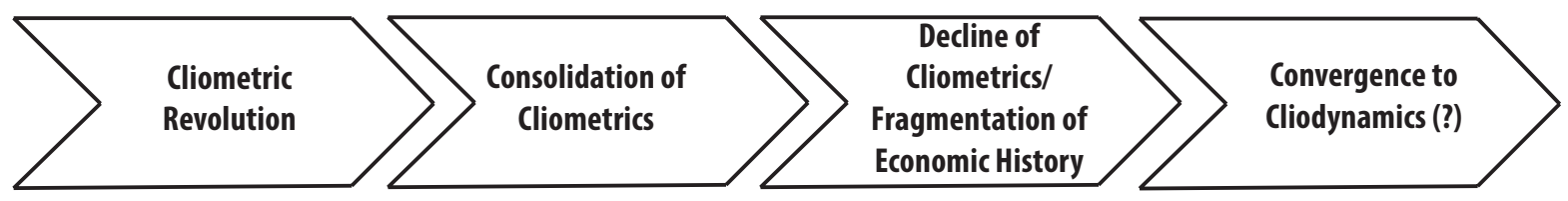

\section{Cliometric Revolution}

Despite the existence of some predecessors, the literature has well defined the inception of Cliometrics as a "revolution", started in the mid-1950s in the American faculties of economics, in particular, at Purdue University. It was a revolution regarding the dominant way of treating history in the Anglosphere until then. The conflict between new economic history (as also was known cliometrics) and old economic history was not trivial and had ancient roots.

1 The surveys on the subject began quite early. Just for mention the most important authors, North (1965, 1974), Davis (1966), Fogel (1966), Scheiber (1967), McClelland (1973) presented general balances of the field in the proximity of the Cliometric Revolution.

2 See Whaples (2010), Hoffman (2010) and Boldizzoni (2011). 
Economic history, by the 1940, was a field dominated by the inheritors of the German historical school. ${ }^{3}$ The German school, which main figure in the Anglophone academic environment was Gustav von Schmoller, emphasized the role of history as the key source of knowledge about human actions and economic matters. An important part of their philosophy about social dynamics was that economic relations were culture-specific, and hence not generalizable over space and time. Therefore, the German school rejected the universal validity of economic theories. In accordance to this, they were in favor of a method based on empirical and historical analysis instead of logic and mathematics (Shionoya, 2005).

In contrast with the old economic historians and its German-historical foundations, the new generation of cliometricians had a complete opposite intellectual heritage, which privileged theory and generalized analysis of society. These were young academics trained in neoclassical economics, ${ }^{4}$ which, as we will see later, based their interpretation of society in general principles, valid throughout space and time. They sustained that the "old economic history" was riddled with errors in economic reasoning and embodied an inadequate approach to causal explanation. Cliometricians insisted in a scientific approach to economic-historical questions; a careful specification of explicit models of the phenomena under analysis (Lyons et al., 2008).

In this context, before the arrival of cliometrics, the usage of general theories for approaching historical phenomena was completely rejected by scholars. Therefore, the efforts in the subject were destined to fail. Maybe the most famous call for more theory in economic history, that had virtually none echo by the time, was an address of Eli Heckscher (1929) to the International Historical Congress at Oslo, entitled A Plea for Theory in Economic History. In that address, for instance, Herckscher pointed out that ignorance of the most basic economic theory by economic historians had led to the absurd proposition that the Roman Empire declined because it had become so large that it had ceased to have any foreign trade (Findlay, 1998).

Some sporadic attempts in the same line were made by Clark (1942) and, in particular, by Kemmerer in the sixth annual meeting of the Economic History Association, at Baltimore in 1946. Even then, in the proximity of the Cliometric Revolution, the academic environment was pretty hostile to these approaches (see Kirkland, 1949).

On the other hand, the usage of quantitative analysis was a not so radical innovation of the Cliometric Revolution. At least one generation before the cliometric revolutionaries, the economic historians began to have interest in measurement. In the decade of 1940s quantitative analysis was already a generalized practice in the field, as Heaton (1942) suggested:

3 The particular way in which the German Historical School influenced the dominant economic history varied through regions; in Britain it was pretty direct. For instance, William Ashley, first president of the Economic History Society at its founding in 1926, was a declared follower of Schmoller. In the United States that influence was rather indirect, via the institutional school (Wright, 2001).

4 Throughout the text it would be used the definition of neoclassical economics offered by Colander (2000). For Colander neoclassical economics was characterized by the following 6 features: focusing on allocation of resources at a given moment in time; accepting some variation of utilitarianism as playing a central role in understanding the economy; focusing on marginal tradeoffs; assuming farsighted rationality; accepting methodological individualism; being structured around a general equilibrium conception of the economy. He makes and effort in differentiate neoclassical economics of modern mainstream economics, that would be also an important conceptual issue in this paper. 
The use of statistics is no new thing to economic historians, but the urge to measure movements, growths, groups, and institutions and to answer such questions as How much? How many? How quickly? Or how representative? Is perhaps the outstanding characteristic of our generation. (Heaton, 1942, p. 731).

The traditional economic historians were not used to employ sophisticated statistical methods. Their main use of data had as purpose the identification of trend changes or comparative differences. However, in contrast with what happened with regard theoretical driven analysis, quantitative economic history was a field with an appropriate recognition way before the arrival of cliometrics.

Actually, a common element in the first generation of cliometricians was also their use of non-advanced statistical methods. As paradoxical as it may seem - due to their vindication of econometrics ${ }^{5}$ - the first cliometricians had much of Clio, but little of econometrics. The methods of data analysis used until the first years of the 70s were, basically, descriptive statistics and, just occasionally, simple linear regressions. To give a simple reference, the greatest symbol of the Cliometric Revolution, Robert Fogel's book Railroads and American Economic Growth had just a couple of linear regression models (Fogel, 1964).

Therefore, what distinguished cliometricians from the old economic historians were the purposes and uses of statistical data. Cliometricians extracted more information of data thanks to the theoretical structure through which they approached empirical problems. The usage of theory allowed them to use data for testing precise hypotheses. For instance, the usage of Input-Output models, or supply and demand models, permitted cliometricians to exploit the same information, used before to merely describe the level of production in different sectors, for capturing the functioning of the economy as a system. As an example, through these methods William Whitney (1968) attempted to determine what impact had the change in demand upon the industrial structure of the United States in the late 19th century. Similarly, John Meyer (1955) used them to estimate how much of the backwardness in British industrial growth during the last quarter of the 19th century (what came to be known as the Victorian climacteric hypothesis) could be attributed to lagging sales of exports. In summary, the data were not only used for describing tendencies; they were an integral part of causal analysis.

\section{Consolidation of Cliometrics}

The interest in cliometrics generalized quickly. After the unusual four-day gathering sponsored by the Economic History Association and the Conference on Research in Income and Wealth in Williamstown, Massachusetts, in the Autumn of 1957, a "cliometrics conference" was made on a regular basis during the 60s. Eventually, cliometricians became the leaders of the Economic History Association.

5 The term cliometrics itself incorporated part of that spirit, but even the term "econometric history" was used as synonym, which for authors like McCloskey (1987), clearly represented an attempt to appropriate the prestige of econometrics. 
By the 1970s no graduate student in economics or history could escape economic history (Whaples, 2010), and the economic history sphere was dominated by cliometrics. The field was stimulated by the diffusion of computers in academics and the progressive advances in their capacities, the awaken interests (due to Cold War) for studying long-run growth of capitalist economies, and the increasing adoption of econometrics in applied economics.

For the mid-70s the Cliometric Revolution had already reached the whole world. ${ }^{6}$ Papers like Fould and McCloskey (1981), Dumke (1992), Grantham (1997), Tilly (2001) and Kalmanovitz (2004) describe that process in different regions.

All that occurred as the consolidation of a paradigm, which could be characterized by fivemain features. ${ }^{7}$ In the first place, cliometricians centered their methods on quantitative analyses. Qualitative research was (almost) completely absent from cliometrics agenda.

A second feature was that cliometricians were interested in extracting information from big samples. That led them to a major effort of data reconstruction and collection. Their main objectives were data on prices, wages and production. Hence, it is not surprising that the periods of analysis of most cliometric studies were those for which that sort of data were available, in particular, the last part of the 19th century and the first of the 20th. For instance, in the 1960s William Parker and Robert Galman were pioneers recollecting and analyzing individual-level data from US census manuscripts of the 19th century. With these data they analyzed the structure of the ante-bellum cotton economy, addressing questions about issues such as slave labor productivity, wealth distribution and regional self-sufficiency in food production (Lyons, Cain \& Williamson, 2008).

Using statistical inference as testing method is the third feature of traditional cliometrics. Cliometrics embraced, eventually, the ultimate econometric methods for the moment. In particular, linear regression models, basing their conclusions on statistical significance.

Forth, cliometrics used, in a systematic and explicit way, counterfactual hypotheses for finding causal relations. A concrete result of this approach was the concept of social savings, developed, precisely, by cliometricians. Social savings is a growth accounting technique designed to evaluate the consequences on growth of incorporating new technology. It estimates the cost-savings of the new technology compared with the next best alternative. That is, it identifies a hypothetical alternative as an application of the concept of opportunity cost.

The reevaluation of railroad's importance in the economic growth of the US is one of the most famous examples of the use of social savings technique. Fogel (1964) and Fishlow (1965) estimated the extent of resource saving that had accrued form the adoption of a transport system with lower costs than those of canals. ${ }^{8}$ Both estimates suggest an effect of nearly $5 \%$ of GNP, which was interpreted as a rather modest number (Lyons et al., 2008).

6 It took almost an extra decade for the first World Congress on Cliometrics to take place. It was held at Northwestern University in 1985. 28 lectures were presented, $46 \%$ of which were on non-U.S economic history. It included countries like Italy, France, Japan, Great Britain, Germany, Ireland and Canada (Rojas, 2007).

7 A careful revision of cliometrics methodology is available in McClelland (1975).

8 Fogel's estimates for 1890 compare railroads with a hypothetical system of canals that would replace the actual railroad system of that date; while Fishlow's estimates for 1859 compare railroads with the existing system of water transport. 
Finally, maybe the most important feature of cliometrics was the use of neoclassical theory as analytical framework. It implied the conception of the market as the natural mechanism of resource allocation and, therefore, prices as reference of value. Regardless that it existed some sort of Keynesian cliometrics in the first part of the Revolution (i.e. Brown, 1956, Matthews, 1954, Rostow, 1948), it was marginal in number of works as in the attention received. I was neoclassical economics the theoretical basis that would remain in cliometrics (Greasley \& Oxley, 2011).

\section{Decline of Cliometrics and fragmentation of economic history}

Despite their success in the rest of the world, for the mid-70s a growing dissatisfaction captured the circles of experts in economic history. The major set of critics came from the usage of neoclassical theory, and how it restricted their capacity of analysis. Neoclassical economics limited the set of questions to ask (to those related with market economies) and became a straitjacket for researchers; quantification and statistical inference were feasible just in a narrow set of problems also. Even authors belonging to the first generation of cliometricians joined this criticism. Among them North $(1974,1977,1978)$, David, Gutman, Sutch, Temin and Wright (1975), McCloskey $(1978,1987)$ and Field (1987).

The internal dissension was compounded by the progressive distance in the methods and interests of history and economics, which put cliometrics in a quite complicated in-between position. Since then, cliometricians started an isolation process, moving away from economics mainstream and quite further from history mainstream. This process generated also the consolidation of a more coherent community of stable size, but much smaller than in the years of the revolution, and clustered in a few particular universities (Rojas, 2007). This community would resolved, until some point, the internal dissension of the late-70s and would became, by the end of the century, the core of what we will make reference in the next section as new cliometrics.

All this activity led to a marginalization of cliometrics that subsists nowadays. As cliometrics was the dominant paradigm in economic history, it was natural to associate its decline with the decline of the whole discipline. Nevertheless, what happened after the decline of cliometrics was a fragmentation of economic history agenda. Those fragments resulted became, eventually, independent branches. Four of them can be recognized today: new cliometrics, new institutional economic history, long-run development approach and very long-term economic history.

The reconfiguration of economic history after the decline of cliometrics is presented in the diagram 2. It describes how the new four branches of economic history resulted from diverse influences, but all of them share common roots in cliometrics. In the following sections we present in more detail the features of each of these branches. 
Diagram 2. Reconfiguration of economic history.

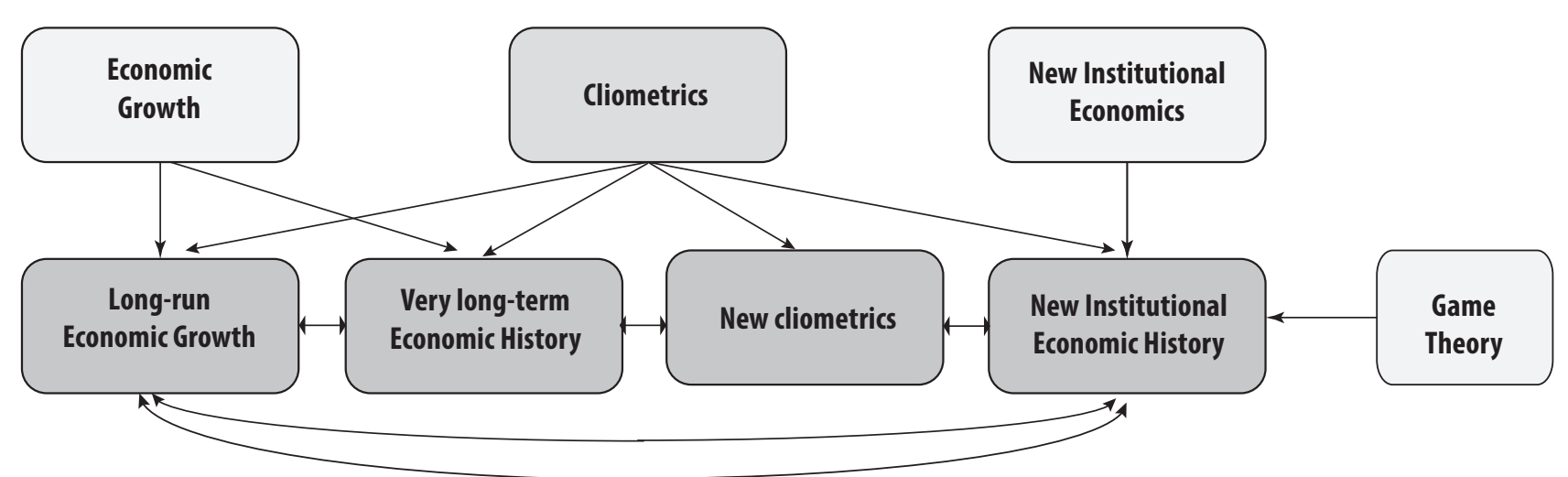

\section{New Cliometrics}

As mentioned above, cliometricians moved away from mainstream economics and gather around a stable academic community. The national associations created during the cliometrics boom and the progressive efforts to extend those institutions generated an international community with a clear identity. Among the symbols of the community at international level are several field journals and global meetings. Based on Google Scholar data, the top 3 journals in the field are the Journal of Economic History, Explorations on Economic History and The Economic History Review, all of which have four issues per year. Meanwhile, the World Economic History Congress and the World Cliometrics Conference are the most representative meetings of the community. They are organized every three years. ${ }^{9}$ The particularities of the community as a relative small and isolated group (with regard to the dominant subfields of economics) allowed them, not only to survive, but to represent the "official" version of economic history in academics. ${ }^{10}$

Despite of following the intellectual project of traditional cliometrics, new cliometrics has made significant advances in the field.

In the first place, there has been an improvement in methodological terms. New cliometricians improved the data collected and the inferences based on them. Accordingly, they have adapted the newest econometric methods, in particular, those developed in time series analyses. Cointegration methods, analysis of convergence, unit root tests, Kalman filters, Granger causality tests, VAR and GARCH models were some of the techniques with more acceptance among new cliometricians (Greasley \& Oxley, 2011a).

On a regular basis the application of the new methods were seen in traditional debates. For example, Crafts and Harley (1992) and Greasley and Oxley (1994) offered new estimates for the economic performance during the British Industrial Revolution. In a similar effort, Crafts, Leybourne and Mills (1989) explored the Victorian climacteric, finding that, contrary to the existing literature, neither Britain or France experienced a slowed down in the trend rate of GDP growth.

9 The frequency of the World Cliometrics Conference has varied in the last 20 years.

10 Baten and Muschallik (2011) offered a detail revision of the international economic history community. 
Additionally, a whole new set of subjects, periods and data sources became part of the regular agenda of new cliometricians. Let me mention some of the more prolific areas.

In one hand, there was a tremendous increase in transnational studies, in particular, related with the origins of globalization, and its effects in different parts of the world. Papers such as Eichengreen (1998), Bordo, Eichengreen and Irwin (1999), Williamson and Bértola (2003), and Bordo, Allan and Williamson (2003) are examples of that literature. On the other hand, this global approach has coexisted with a more recent involvement into intranational dynamics. A wave of studies which try to reconstruct regional GDP series are the first part of an ambitious agenda that pretends to have a complete map on regional disparities around the world. This literature began with Geary and Stark (2002) and Crafts (2005) for the UK. Many studies have followed them; offering new series of estimates for countries like Belgium (Buyst, 2011), Spain (Rosés et al., 2010, Martínez-Galarraga et al., 2013), the Austro-Hungarian Empire (Schulze, 2007), Italy (Felice, 2011), Portugal (Badia-Miró et al., 2012), Colombia (Mejía, 2015), Sweden (Enflo, Henning \& Schön, 2010) and India (Caruana-Galizia, 2013).

In a similar line, financial history also enjoyed of large attention, with an ambivalent emphasis on international financial relations and more detailed analyses of local financial institutions. Almost all this literature focuses in the $19^{\text {th }}$ and the first part of $20^{\text {th }}$ century. For instance, while Eichengreen (1992) reevaluated the Great Depression based on the role of the international monetary system, Bernanke (1983) explored the non-monetary determinants of its propagation in the US. Other papers in this line that founded complete research agendas are Eichengreen (1993, 1998), Bordo and Rockoff (1996) and Marichal (1989). Recently, an explosion of general revisions of financial crisis has taken place. Great reception in the general public had books like Ferguson (2008), Reinhart and Rogoff (2009), Marichal (2010), and reissues of Kindelberger (2009).

Notwithstanding the permanent advances and regular productivity of new cliometricians, they remain focus on periods and topics in which standard economics methods are convenient. This element has restricted their capacity to offered new fields of study that could attract the attention of researchers outside cliometrics community, something in which the other branches of economic history have been more successful.

\section{New institutional economic history}

The importance of institutional framework in historical analyses was realized by the early cliometricians. Even though, they did not included it as a property of their general models, ${ }^{11}$ but as a descriptive element of the context. Just with the passing of time and the consolidation of other branches of new institutional economics (see Hodgson, 1993, Klein, 2000), institutions turned into the center of economic historians interest. ${ }^{12}$ The most relevant link between the old cliometrics and the new institutional economic history is, with no doubt, Douglass North.

11 As it will be argued, Douglass North is a major exception, in particular, his papers with Lance Davis (Davis \& North, 1971) and with Paul Thomas (North \& Thomas, 1973).

12 Greif (1996) offers an analysis of the rebirth of institutions on economic history. 


\section{Econometrics tradition}

North (1990) presents institutions as the rules of economic interactions. It became the basic analytical framework for explaining the ways in which institutions and institutional change affect economic performance, both at a given time and over time. Based on that framework, the last 15 years experienced a complete explosion in the field of institutions an economic history. ${ }^{13}$ Most of the studies in this literature try to interpret modern economic disparities through the historical persistence of institutions. ${ }^{14}$ For instance, Acemoglu, Johnson and Robinson (2001) suggest that the colonization pattern of Europeans describes a significant share of the current institutions of former colonialized nations and their different economic performance. Banerjee and lyer (2005) explore the colonial land revenue institutions set up by the British in India, showing that differences in historical property rights institutions led to sustained differences in economic outcomes between regions.

In a similar direction, but with an emphasis in financial markets, authors like La Porta, Lopez-de-Silanes, Shleifer and Vishny (1998), and Beck, Demirguc-Kunt and Levine (2003) explore the effect of legal origin on the quality of property rights protection. They conclude that the legal institutions that were transplanted by the different colonial powers had long-term consequences for financial development.

All these exercises were made with similar empirical methods than those of the old cliometricians (i.e. statistical inference), approaching institutions through a quantitative proxy. Following a slightly different approach, using a rather narrative argument and reflecting in a more general way about the concept of institutions, Engerman and Sokoloff (2002) support similar hypotheses. They assure that depending on geographical conditions in their colonies, European colonizers adopted different strategies for colonial exploitation, and those strategies generated different institutional trajectories in these colonies, and, eventually, different economic performance.

\section{Game theory tradition}

Also as part of the new institutional economics agenda, but with a deeper concern about the microfoundations of institutional change, a growing literature was established in the last decade. Using game theory, authors like Binmore (2010) and Greif (2008) have offered an alternative to Douglass North's way of modeling institutions as the rules in a game. They prefer to focus on social norms as the equilibrium selection devices in the game of life. The objective of the studies in this tradition is not to identify the effects on economic performance of institutional persistence, but to explore how the modern institutional and economic environment is the result of previous interactions of economic behavior and other institutional arrangements.

13 It is interesting to realize that the rebirth of institutions represents a return to the origins of economic history. Heaton (1942) presented as the main character of what he called the first generation of economic historians (he mean by that authors like Ashley, Cunningham, Schmoller, Levasseur and Toynbe), their interest in institutions, commercial policy and regulations.

14 See Bluhm and Szirmai (2012) for an analytic literature review. 
As mentioned, game theory is the conceptual ground of this line of research. Greif (2002) summarizes the use of game theory in economic history. The ability of game theory for describing multiple equilibrium scenarios offers a theoretical basis for comprehending how different historical trajectories are possible in identical situations (in terms of their endowment, preferences, and technology). In other words, it allows economic history to incorporate the old historical idea that economic actors can potentially matter, and that the non-economic aspects of the historical context, such as religious and cultural precedents or even chance, can influence economic outcomes. This is a main feature that regular neoclassical economics does not provide, and that old historians employed to criticize cliometrics. In that sense, this literature is offering the microfoundations of historical change (Greif, 1997).

Despite that some of the studies on this tradition are mainly theory driven, there is a permanent reflection on its coherence with historical evidence. As their purposes are different from those of cliometrics, so are their empirical testing methods. While most cliometrics relied on single equation models and made limited use of simultaneous equations and stochastic trends, this literature has tended to combine quantitative and qualitative evidence by using categorical variables. There is also a frequent non-statistical inference approach (Casson \& Hashimzade, 2013). For instance, Greif (2006), one of the main references on the subject, does not use a single regression on its 527 pages. It focuses on how well historical facts (many of them qualitative) coincide with the predictions of the models. In particular, he examines the economic institutions emerged during the 11 th century to facilitate complex trade, which was characterized by asymmetric information and limited legal contract enforceability. He concludes that the theoretical framework used explains many trade-related phenomena, especially why traders utilized specific forms of business association, and indicates the interrelations between social and economic institutions. Notice that the statistical inference abdication allowed him to approach institutions in a more complex way than those of the econometric tradition of new institutional economic history, which need particular institutional proxies for running their regressions. ${ }^{15}$

Bates, Greif, Levi, Rosenthal \&Weingast (1998) proposed analytic narratives as a research project that gathered the methodological concerns of this tradition. They proposed the need for a method that interprets, based on rational choice theory (i.e. game theory), the qualitative data from historical narratives. ${ }^{16}$ After an active discussion in the years that followed the publication of Bates et al. (1998) (see Bates et al., 2000a, 2000b), the attention to analytic narratives decay. It remains an active field in political sciences. However, despite the increasing interest in the same methodological resources in economics literature, very few of those studies identify themselves as part of analytic narratives.

15 As we will see, this sort of empirical testing methods, which are closer to the simulation methods used in natural sciences and other economics fields, as modern macroeconomics, are gaining acceptance among economic historians.

16 In Bates et al. (1998) this approach can be traced back to Modernization theorists (Lipset 1963), Marxists (Lefebre 1924), world system theorists (Wallerstein 1974), and others (such as the Whig historians, e.g., Trevelyan 1938). More recently, King, Keohane, and Verba (1994), and Green and Shapiro (1994).

tiempo\&economía

Vol. $2 \mathrm{~N}^{\circ} 2$ - II semestre de 2015 


\section{Long-run development approach}

In recent years, some of the most distinguished authors in economic development have focused on the measurement of the effects of historical variables on contemporary income. Their hypothesis is that economic development is affected by traits that have been transmitted across generations over the very long run. Not all of those studies can be considered historical work - for example Rodrik, Subramanian and Trebbi (2004), Easterly and Levine (2012) or Tabellini (2010). However, a particular line in this agenda is deeply involved in economic history and is capturing each time more public attention.

Nunn (2009), and Spolaore and Wacziarg (2013) present surveys of this literature, in which this section is primarily based.

In general terms, there are three different channels through which historical events may impact current economic development.

The first channel are institutions. We talk about it extensively in the previous section. Just for closing the argument, this agenda could be considered one the most successful in economics in the last 10 years. A clear evidence of that is the impressive editorial success of Acemoglu and Robinson (2012). Its success can also be identified in the great number of scholars, all over the world, that have gotten involved in institutional studies. This global fever for the institutional determinants of growth, taken advantages of local historical data poorly explored in the past, have made considerable improvements in the comprehension of political history and its interaction with economic activity.

The second channel is geography. Maybe the main reference in this channel is Diamond (1997). He suggests that the roots of comparative development rest on a series of environmental advantages enjoyed by Eurasia during the Neolithic Revolution. These advantages included the larger size of the continent, its initial biological conditions (i.e. the diversity of animals and plants available for domestication), and its East-West orientation, which facilitated the spread of agricultural innovations. Due to these geographic advantages, Eurasian civilizations experienced a population explosion and an earlier acceleration of technological innovation, with long-term consequences on their welfare conditions.

Compared with Acemoglu and Robinson, Diamond (1997) has generated a much smaller group of followers. Even though, papers like Olsson and Hibbs (2005) have found significant empirical evidence in favor of his theory. Recent literature, following Ashraf and Galor (2013a, 2013b), seems to sympathize with a more indirect mechanism in which geography might have matter. They suggest that it was the effect of geography in the isolation of social groups; not directly, but through cultural diversity; what would have determined their long-term economic performance.

The third channel is biological transmission. This channel refers to the importance of abilities and habits transmitted across generations. The transmission may be through genetic or cultural tracts. The genetic tract is presented in Galor and Moav (2002), while the cultural tract is described by Clark (2008). Both of them have, basically, the same hypothesis. It consists in the idea that a Malthusian trap (i.e. a prolonged economic stagnation, prior to the transition to sustained growth) stimulated a natural selection process that shaped the attributes of population that would survive in the long-run. Eventually, society would have a larger presence of the most 
powerful and efficient attributes, leading to the origin of the take-off from an epoch of stagnation to sustained growth. In other words, those theories explain the escape from Malthusian traps as an endogenous evolutionary process. The main difference between cultural and genetic visions is that the cultural vision suggests that what were transmitted were the most successful values and habits, not the successful gens as the genetic vision proposes.

The rest of the literature on the biological channel has focused on the particular mechanism through which this generational transmission has occurred. For example, Doepke and Zilibotti (2008) offered a model in which altruistic parents shape their children preferences in response to economic incentives, resulting in the transmission of values across generations. Due to the incorporation of imperfect financial markets, the model predicts that middle-class families in occupations requiring effort, skill, and experience developed patience and work ethic. Meanwhile, upper-class families relying on rental income cultivate a refined taste for leisure. They argue that this can explain the social pattern of the British Industrial Revolution, in which industrial capitalists raised from the middle-classes as the economically dominant group.

\section{Very long-term economic history}

Despite of lacking from a clear identity, an increasing number of authors have been interested in a very long-term (in some cases, millennial) view of economic history. Most of them have a similar objective to the one of long-run development researchers, the comprehension of current international disparities. Even though, this literature has a deeper commitment in the description of historical processes and the evolution of economic structure per se. Therefore, in this literature are also situated the each time larger number of studies on medieval and ancient economics (see Scheidel, Morris \& Saller, 2007, Pamuk, 2007, Stasavage, 2007, Deng, 2013, Andersen, Jensen, Skovgaard, 2013, Ober, 2015).

\section{Unified growth theory tradition}

The origins of this literature is quite diverse. As just mentioned, some authors are pretty close to long-run development studies. For instance, Kremer (1993) constructs and tests empirically a model of world population growth between one billion B.C. to 1990, combining the idea that high population spurs technological change with the Malthusian assumption that technology limits population. The model predicts that over most of history, the growth rate of population was proportional to its level. His empirical tests, based on statistical inference, support this prediction and show that historically, among societies with no possibility for technological contact, those with larger initial populations had faster technological change and population growth. Similarly, Ashraf and Galor (2011) confirm that improvements in the technological environment during the Malthusian era had generated only temporary gains in income per capita, eventually leading to a larger, but not richer, population. They use statistical inference as Kremer, but exploit an exogenous source of variations in technological progress.

Kremer, and mainly Galor, influenced a large set of studies that, eventually, would be integrated in the Unified Growth Theory, which was the title that Galor $(2005,2011)$ gave to the 
research agenda that tries to capture in a single theoretical framework the millennial dynamics of economic growth. Through particular ways of interacting fertility, human capital accumulation and technological progress, they manage to develop models that predict the succession of stages that, in their view, have characterized human economic history (i.e. Malthusian epoch, post-Malthusian regime, and modern growth).

Based on Unified Growth Theory, authors like Voth and Voigtländer $(2006,2013)$ have explored the transition to sustained economic growth in different contexts. Their approach consists in developing particular versions of Unified Growth Theory models, testing them empirically through calibration and simulation. This is basically the same methodological approach of modern macroeconomics, which is based on the simulation of DGSE models. Voth and Voigtländer find that population dynamics, rather than productivity growth, were the key determinants of the transition to higher and sustained economic growth rates in the world.

\section{The cliometric tradition}

Another important part of very long-term economic history is closely related with new cliometrics and has been particularly influential in the Netherlands and the UK.

A key step in the consolidation of this line was made by Angus Maddison, who guided a global project of national accounts historical reconstruction (see Maddison, 2007a, 2007b, 2007c), which propelled a tremendous amount of quantitative studies in macroeconomic history all over the world. The presence of Maddison in Groningen University helped to consolidate an important group of authors influenced by his ideas in the region. Researchers such as Jan Luiten van Zanden, Bas van Bavel and Ewout Frankema are part of that group. All these authors can be also cataloged as new cliometricians; even though, their interest in pre-industrial processes usually lead them to slightly different research questions and methods. For example, recently van Bavel, Campopiano and Dijkman (2014) explored through a qualitative approach the organization and development of factor markets in early medieval Iraq. Therefore, their work can be considered far from new cliometrics in methodological terms, but close, theoretically speaking. Similarly, Frankema (2013), focusing his attention in precolonial Africa, argues about the importance of environmental variables (usually poorly explored in regular cliometrics) in the emergence of economies of scale and division of labor (a traditional question in neoclassical economics).

Authors like Allen $(2000,2001)$ follow a similar tradition. He offers a history of the economic structure of Europe since the Middle Ages. His emphasis is on the dynamics of the market economy. So, as the old cliometricians, one of his main contributions is the reconstruction of time series (prices, wages and production). However, non-market questions are also part of this tradition, for example, Clark (2014) analyzes social mobility in the very long-run. Using rare surnames to track families, he argues that wealth is much more persistent over generations than standard one generation estimates would suggest. He also argues that those figures are impervious to institutions. In almost all societies it takes hundreds of years for descendants to shake off the advantages and disadvantages of their ancestors. Genealogical data and different proxies of social status are some of the new sources that this tradition has incorporated to the usual analysis of old cliometricians. 


\section{Links between branches}

As described above, each of the branches in which economic history was fragmented has a different intellectual and methodological spirit. However, they are not isolated fields of study. In fact, almost all the authors mentioned above have key contributions in each of these branches. It is not only difficult to categorized authors, the frontier between branches is blurry itself.

Just to mention some recent influential studies, Acemoglu and Robinson (2012) and North, Wallis, Webb and Wiengast (2007) are general reflections on long-run economic development that are based on strictly institutional arguments. In a similar line, Greif (2006) presents a general analysis of how economic activity shaped the long term evolution of institutions. In that sense, all of these three works could be considered part of the new institutional economic history or of the long-run economic development approach.

Similarly, Comin, Easterly and Gong (2010), just as Kremer (1993), have clear economic growth questions, but their so long period of analysis inevitably puts them in the long-term economic history sphere. This is a general claim for all the Unified Growth Theory tradition.

Moreover, some literature that could be considered part of Unified Growth Theory tradition relates closely with new cliometrics. For instance, Galor and Mountford (2009) explore the effects of trade on population dynamics, human capital accumulation and economic performance. They offer evidence from the $19^{\text {th }}$ and $20^{\text {th }}$ century, being close to new cliometrics in their subject of study and their period of analysis. On the other hand, Michalopoulos and Papaioannou (2013), and all the state history literature related with them, use regular microeconometrics as empirical approach, not the simulation method of other Unified Growth Theorists such as Voth and Voigtlänler $(2006,1013)$. In that sense, they are closer to new cliometrics.

This last example shows that, besides sharing thematic objectives, in some cases, these branches share methodological and empirical approaches. Once again, just as illustration, Doepke and Zilibotti (2008) use similar methods of those of new institutionalist, presenting a behavioral model and then testing its implications with qualitative information about the Industrial Revolution, which, by the way, is a period of particular involvement of cliometricians.

As we will argue, those links among economic history branches are precisely what seems to predict the convergence to a more general approach, cliodynamics.

\section{Cliodynamics}

The term cliodynamics was coined by Peter Turchin, in the early 2000s. He pretended to incorporate a concept which took distance from the data and focused on the mechanisms behind historical evolution (Turchin, 2013). As a comunitity it has emerged congregating a small group of researchers of different sciences interested in a formal study of social history. In that sense, cliodynamics studies have as common element a particular methodological view of history analysis rather than a common thematic focus. In fact, cliodynamics has a wide spectrum of interests. It not only focuses on traditional economic topics. Actually, most part of the literature, 
calling itself cliodynamics, is not referred to market economies, but to ancient and prehistoric societies. Therefore, it has a closer relation with fields that just sporadically had contact with old cliometrics, as paleontology, archeology, and population genetics. In that sense, Cliodynamics has a wider object of study, the evolution of societies over time.

The cliodynamics community has grown considerably in the last years. A peer-reviewed journal specialized on the subject was founded in 2010 and by now it publishes two issues per year. An increasing number of authors with significant recognition in different areas, such as history, complex systems and ecology, have turned the focus of their research agendas to cliodynamics. Among those, we could mention people like John Gaddis, Kenneth Pomeranz, John Robert McNeill and David Krakauer.

Cliodynamics share the scientific ambitions of early cliometrics, considering that if we have the right quantitative tools and historical data it is possible to test general theoretical descriptions of history (see Turchin, 2011). This feature makes that cliodynamics researchers keep similar efforts of data recollection and big sample estimates as those of cliometricians. For example, Turchin, Whitehouse, Francois, Slingerland and Collard (2012) introduce a historical and archaeological database that pretends to be used for interpreting the process through which humanity began to cooperate in large groups of genetically unrelated individuals. At the end of the day, they test hypotheses related with the interaction of resources, warfare, ritual, and religion dynamics of social groups.

Nevertheless, the differences between cliodynamics and cliometrics are important. In the first hand, the involvement of cliodynamics in periods in which human groups were more vulnerable to the natural environment emphasizes the role of ecological context, in particular the biological determinants of human interaction. Most of those phenomena are not quantitative, which implies an accent on qualitative analyses that was absent in cliometrics. For example, Grinin, Markov and Korotayev (2013) study the hyperbolic pattern of world population growth, arguing that it was resulted from the feedback between demographic growth and technological development through an analogue of the collective learning mechanism in biology.

The proximity of cliodynamics to natural sciences has also influenced its methodological approach. The dominant methods in cliodynamics are the usual mathematical and computational techniques used on those sciences, such as agent-based models, power-law relations, and traditional differential-equation models.

Complex systems have been also a central source of inspiration for cliodynamics. Thus, the frequent use of social network analysis and evolutionary game theory characterizes this literature. For instance, Turchin and Gavrilets (2009) based on those tools argue that large-scale hierarchically complex societies arose as a result of evolutionary pressures brought on by warfare.

At an empirical level, cliodynamics has also followed the dominant testing methods in natural sciences and complex systems, mainly, simulations of calibrated models and statistical inference of time series models (see Turchin, 2005). With those empirical methods, Turchin (2010) validates the relevance of environmental endowments in the thesis of Turchin and Gavrilets (2009). 


\section{Is economic history converging to cliodynamics?}

Throughout the text we mentioned a large set of elements in the recent literature on economic history that suggests an eventual convergence to cliodynamics.

In the first place, almost all the branches of economic history have expanded their periods of analysis further from the well-established capitalism. Thereby, they have recovered a broader conception of human behavior, not focused on markets, but rather on how people interact repeatedly with each other and with their environment. In that sense, it is not surprising that natural endowments, technological change and institutional arrangements are progressively substituting prices and production as the key variables of study.

In that process, game theory, institutional analyses and recent advances on behavioral economics have been introduced regularly in economic history, offering a wider theoretical framework, similar to the eclectic vision proclaimed by cliodynamics.

Additionally, in coherence with this shift in the conceptual vision, the revitalization of non-quantitative data is another trend in the research agenda of economic history that coincides closely with cliodynamics. This has been possible thanks to the adoption of more flexible empirical tools than those used by the first cliometricians. The diffusion of nonlinear models, time series analysis and simulation methods are part of that process.

It is important to notice that the convergence referred here is a convergence in research agendas. It does not mean that economic history community would be eclipsed by cliodynamics community. In fact, as academic communities, all the branches of economic history are far more structured than cliodynamics groups. Probably that would imply absorption of the latter by the former, if their research agendas continue to converge.

An example of the convergence of economic history and cliodynamics is the book edited by Diamond and Robinson (2011). It congregates a large variety of authors of different sciences, some of them closer to cliodynamics, such as Sthephen Haber or Patrick Kirch, and others closer to economic history, such as Daron Acemoglu and Nathan Nunn. The book is characterized by its heterogeneity. In one hand, it ranges from a non-quantitative narrative style (traditional among historians) to quantitative studies with statistical analyses (typical of cliometricians). On the other hand, the book studies a range of societies that goes from contemporary to prehistorical ones. However, all of the chapters of the book have in common the usage of exogenous and unexpected events as a way of applying natural experiment methods. And it is precisely that heterogeneity in particular methods, but the acceptance of a formal and rigorous view of human history what defines cliodynamics.

\section{Final remarks}

This paper argues that economic history has been an active field in economics during the last 65 years. This is not the first time such a claim is made. Several other authors have identified, as well, that economic history remains influential among mainstream economics (see Mokyr, 2010, Cain \& Whaples, 2013, Diebolt and Haupert (2015a), Abramitzky, 2015). For those authors, the 
improved prestige and influence of economic historians, and the increasing presence of economic history publications in the top economics journals are clear evidence of a renewed interest for history in economics. However, all those authors fail to identify the disruptions in the evolution of economic history. This paper presents a nonlinear history of the field.

We found two dimensions of disruption in economic history. In one hand, there was a temporal dimension. The field evolved in time in a non-monotonic way. The production and interest in the economic history expanded rapidly during the 50s and 60s; it decayed in the 70s and 80s and has resurrected sin the mid-90s. On the other hand, there was a conceptual dimension of disruption. In some moments, economic history studies converged to a unique paradigm, while in others, they diverged. Cliometrics was the unified paradigm in the $60 \mathrm{~s}$. The $70 \mathrm{~s}$ and $80 \mathrm{~s}$ saw the divergence of economic history studies. During the $90 \mathrm{~s}$, new cliometrics, new institutional economic history, long-run development approach and very long-term economic history consolidated as independent intellectual agendas. Finally, the last couple of decades have been characterized by a convergence on those agendas. Cliodynamics stands as a possible new unified paradigm.

Therefore, this paper argues against authors like Diebolt and Haupert (2015b), who claim that cliometrics remains a unified conceptual body that gathered all the efforts in formal economic history. We, in contrast, consider that cliometrics, as an intellectual tradition, has a limited scope. Despite that all the current branches of economic history have roots in cliometrics, they are closer to other conceptual traditions. Their different questions, methods and theoretical background prove it.

On the other hand, cliodynamics, characterized by a flexible formal approach to history, seems to be a more plausible unified paradigm. Clearly, the convergence to cliodynamics that we propose is a conjecture that deserves a deeper analysis. The origins of cliodynamics from outside economics might be a serious restriction. The future evolution of cliodynamics itself also generates uncertainty about the predicted convergence. Additional studies from the core of cliodynamics must be done. As well as closer explorations of the economic history community. The availability of big data on journal publications and citations are some of the potential new sources that could enrich this discussion.

\section{References}

Abramitzky, R. (2015). Economics and the Modern Economic Historian (No. w21636). National Bureau of Economic Research.

Acemoglu, D., Johnson, S., \& Robinson, J. A. (2000). The colonial origins of comparative development: An empirical investigation (No. w7771). National Bureau of Economic Research.

Acemoglu, D., \& Robinson, J. A. (2012). Why nations fail: the origins of power, prosperity and poverty. New York: Crown Business.

Andersen, T. B., Jensen, P. S., \& Skovsgaard, C. V. (2013). The heavy plough and the agricultural revolution in medieval Europe. Discussion Papers on Business and Economics. University of Southern Denmark, 6. 
Ashraf, Q., \& Galor, O. (2011). Dynamics and Stagnation in the Malthusian Epoch. The American Economic Review, 101(5), 2003-2041.

Ashraf, Q. \& Galor, O. (2013a). Genetic diversity and the origins of cultural Fragmentation. The American Economic Review, 103(3), 528-533.

Ashraf, Q., \& Galor, O. (2013b). The "Out of Africa” Hypothesis, Human Genetic Diversity, and Comparative Economic Development. The American Economic Review, 103(1), 1-46.

Badia-Miró, M., Guilera, J., \& Lains, P. (2012). Regional incomes in Portugal: Industrialisation, integration and inequality, 1890-1980. Journal of Iberian \& Latin American Economic History, 30(2), 225-244.

Banerjee, A. V., \& lyer, L. (2002). History, institutions and economic performance: the legacy of colonial land tenure systems in India.

Baten, J., \& Julia, M. (2011). On the status and the future of economic history in the world. MPRA Paper 34704. University Library of Munich, Germany.

Bates, R. H., Greif, A., Lev, M., Rosenthal, J. L., \& Weingast, B. R. (1998). Analytic narratives. Princeton University Press.

Bates, R. H., Greif, A., Lev, M., Rosenthal, J. L., \&Weingast, B. R. (2000a). The Analytic Narrative Project. American Political Science Review, 94(3), 696- 702.

Bates, R. H., Greif, A., Levi, M., Rosenthal, J. L., \& Weingast, B. R. (2000b). Analytic Narratives Revisited. Social Science History, 24(4), 685-696.

Beck, T., Demirgüç-Kunt, A., \& Levine, R. (2003). Law, endowments, and finance. Journal of Financial Economics, 70(2), 137-181.

Bernanke, B. S. (1983). Nonmonetary effects of the financial crisis in propagation of the great depression. American Economic Review, 73(3), 257-276.

Bértola, L., \& Williamson, J. G. (2003). NBER Working Papers 9687. National Bureau of Economic Research, Inc, May 2003.

Binmore, K. (2010). Game theory and institutions. Journal of Comparative Economics, 38(3), 245252.

Bluhm, R., \& Szirmai, A. (2012). Institutions and long-run growth performance: An analytic literature review of the institutional determinants of economic growth. MERIT Working Papers 033. United Nations University - Maastricht Economic and Social Research Institute on Innovation and Technology (MERIT).

Boldizzoni, F. (2011). The poverty of Clio: Resurrecting economic history. Princeton University Press.

Bordo, M. D., Eichengreen, B., \& Irwin, D. A. (1999). Is Globalization Today Really Different than Globalization a Hunderd Years Ago? (No. w7195). National Bureau of Economic Research.

Bordo, M. D., \& Rockoff, H. (1996). The gold standard as a "good housekeeping seal of approval". The Journal of Economic History, 56(2), 389-428.

Bordo, M. D., Taylor, A. M., \& Williamson, J. G. (Eds.) (2007). Globalization in historical perspective. University of Chicago Press. 
Buyst, E. (2011). Continuity and change in regional disparities in Belgium during the twentieth century. Journal of Historical Geography, 37(3), 329-337.

Cain, L. P., \& Whaples, R. (2013). Economic history and cliometrics. The Routledge Handbook of Modern Economic History, 3.

Caruana-Galizia, P. (2013). Indian regional income inequality: estimates of provincial GDP, 18751911. Economic History of Developing Regions, 28(1), 1-27.

Casson, M., \& Hashimzade, N. (2013). Large Databases in Economic History: Research Methods and Case Studies. Routledge. Clark, G. (2008). A Farewell to Alms: A Brief Economic History of the World: A Brief Economic History of the World. Princeton University Press.

Clark, G. (2014). The Sun Also Rises: Surnames and the History of Social Mobility: Surnames and the History of Social Mobility. Princeton University Press.

Colander, D. (2000). The death of neoclassical economics. Journal of the History of Economic Thought, 22(2), 127-143.

Comin, D., Easterly, W., \& Gong, E. (2006). Was the Wealth of Nations determined in 1000 BC? (No. w12657). National Bureau of Economic Research.

Crafts, N. F., \& Harley, C. K. (1992). Output growth and the British industrial revolution: a restatement of the Crafts-Harley view. The Economic History Review, 45(4), 703-730.

Crafts, N. F., Leybourne, S. J., \& Mills, T. C. (1989). The climacteric in late Victorian Britain and France: a reappraisal of the evidence. Journal of Applied Econometrics, 4(2), 103-117.

Crafts, N. (2005). Regional GDP in Britain, 1871-1911: some estimates. Scottish Journal of Political Economy, 52(1), 54-64.

Gutman, H. G., Sutch, R., Temin, P., \& Wright, G. (1977). Reckoning with slavery. Oxford University Press.

Davis, L. (1966). Professor Fogel and The New Economic History. The Economic History Review, 19(3), 657-663.

Davis, L. E., North, D. C., \& Smorodin, C. (1971). Institutional change and American economic growth. Cambridge University Press, 1971.

Deng, K. (2013). Demystifying growth and development in North Song China, 960 -1127. London School of Economics and Political Science, Department of Economic History.

Diamond, J., \& Robinson, J. A. (2010). Natural experiments of history. Harvard University Press.

Diebolt, C., \& Haupert, M. (2015) Handbook of Cliometrics. Springer.

Diebolt, C., \& Haupert, M. (2015) Clio's Contributions to Economics and History. Working papers. Association Francaise de Cliométrie. No. 2.

Jared, D. (1997). Guns, germs, and steel: the fates of human societies. NY: WW Norton \& Company.

Zilibotti, F., \& Doepke, M. (2008). Occupational Choice and the Spirit of Capitalism. Quarterly Journal of Economics, 123(2), 747-793.

Easterly, W., \& Levine, R. (2012). The European origins of economic development. NBER Working Papers 18162. National Bureau of Economic Research, Inc, June. 
Eichengreen, B. (1993). Elusive stability: essays in the history of international finance, 1919-1939. Cambridge University Press.

Eichengreen, B. J. (1998). Globalizing capital: a history of the international monetary system. Princeton University Press.

Enflo, K., Henning, M., \& Schön, L. (2014). Swedish regional GDP 1855-2000: Estimations and general trends in the Swedish regional system. Research in Economic History, 30, 47-89.

Felice, E. (2011). Regional value added in Italy, 1891-2001, and the foundation of a long-term picture. The Economic History Review, 64(3), 929-950.

Ferguson, N. (2008). The ascent of money: A financial history of the world. Penguin.

Field, A. J. (1987). The future of economic history. Springer Netherlands.

Findlay, R. (1998). A plea for trade theory in economic history. The Economic and Social Review, 29(4), 313-321.

Floud, R., McCloskey, D. N., \& McCloskey, D. N. (Eds.) (1994). The economic history of Britain since 1700: 1700-1860. Cambridge University Press.

Fogel, R. W. (1966). The new economic history. The Economic History Review, 19(3), 642-656.

Fogel, R. W. (1965). Railroads and American Economic Growth: Essays inEconometric History. Business History Review, 39(1), 130.

Frankema, E. (2014). Africa and the Green Revolution A Global Historical Perspective. NJAS-Wageningen Journal of Life Sciences, 70, 17-24.

Galor, O. (2005). From stagnation to growth: Unified Growth Theory. In: P. Aghion \& S. Durlauf (Eds.), Handbook of Economic Growth. Amsterdam: Elsevier.

Galor, O. (2011). Unified growth theory. Princeton University Press.

Galor, O. \& Moav, O. (2002) Natural Selection and The Origin Of Economic Growth. The Quarterly Journal of Economics, 117(4), 11331191.

Galor, O., \& Mountford, A. (2008). Trading population for productivity: theory and evidence. The Review of economic studies, 75(4), 1143-1179.

Geary, F., \& Stark, T. (2002). Examining Ireland's Post-Famine Economic Growth Performance. The Economic Journal, 112(482), 919-935.

Grantham, G. (1997). The French cliometric revolution: A survey of cliometric contributions to French economic history. European Review of Economic History, 1(3), 353-405.

Greasley, D., \& Oxley, L. (1994). Rehabilitation sustained: the industrial revolution as a macroeconomic epoch. The Economic History Review, 47(4), 760-768.

Greasley, D., \& Oxley, L. (2010). Clio and the economist: making historians count. Journal of Economic Surveys, 24(5), 755-774.

Greasley, D., \& Oxley, L. (2010). Cliometrics and time series econometrics: some theory and applications. Journal of Economic Surveys, 24(5), 970-1042. 
Greif, A. (1996). Micro theory and recent developments in the study of economic institutions through economic history. In: David M. Kreps and Kenneth F. Wallis (eds.) Advances in Economic Theory. Cambridge University Press.

Greif, A. (1997). Cliometrics after Forty Years. American Economic Review,87(2), 400-403.

Greif, A. (2002). Economic history and game theory. In: Robert Aumann and Sergiu Hart (eds.) Handbook of Game Theory with Economic Applications.1989-2024.

Greif, A. (2006). Institutions and the path to the modern economy: Lessons from medieval trade. Cambridge University Press.

Greif, A. (2008) The normative foundations of institutions and institutional change. In: The Dynamics of Institutions. Paris.

Green, D. P., Shapiro, I., \& Shapiro, I. (1994). Pathologies of rational choice theory: A critique of applications in political science. New Haven: Yale University Press.

Grinin, L., Markov, A., \& Korotayev, A. (2013). On similarities between biological and social evolutionary mechanisms: Mathematical modeling. Cliodynamics: The Journal of Theoretical and Mathematical History, 4(2), 185-228.

Heaton, H. (1942). Recent Developments in Economic History. The American Historical Review, 47(4), 727-746.

Hoffman, P. T. (2010). Response to Robert Whaples. Historically Speaking, 11(2), 20-22.

Heckscher, E. F. (1929). A plea for theory in economic history. Economic History, 1, 525-535.

Hodgson Geoffrey, M. (1993). Institutional Economics: Surveying the "Old" and the "New". Metroeconomica, 44(1), 1-28.

Lyons, J. S., Cain, L. P., \& Williamson, S. H. (Eds.) (2007). Reflections on the cliometrics revolution: conversations with economic historians. Routledge.

Kalmanovitz, S. (2004). La cliometría y la historia económica institucional: reflejos latinoamericanos. Historia Crítica, 27, 63-89.

Kindleberger, C. P., \& Aliber, R. Z. (2011). Manias, panics and crashes: a history of financial crises. Palgrave Macmillan.

King, G., Keohane, R. O., \& Verba, S. (1994). Designing social inquiry: Scientific inference in qualitative research. Princeton University Press.

Kirkland, E. C. (1949). The Place of Theory in Teaching American Economic History. The Journal of Economic History, 9(S1), 99-102.

Klein, P.G. (2000). New institutional economics. Encyclopedia of Law and Economics. Edward Elgar.

Kremer, M. (1993). Population growth and technological change: one million BC to 1990. The Quarterly Journal of Economics, 108(3), 681-716.

La Porta, R., Lopez-de-Silanes, F., Shleifer, A., \& Vishny, R. W. (1998). Law and Finance. The Journal of Political Economy, 106(6), 1113-1155.

Lefebre, G. (1924). Les Payasans du Nord Pendant la Revolution Francaise. Paris: Rieder. 
Lipset, S. M. (1963). The First New Nation: The United States in Historical and Comparative Perspective. New York: Basic Books.

Lyons, J. S., Cain, L. P., \& Williamson, S. H. (Eds.) (2007). Reflections on the cliometrics revolution: conversations with economic historians. Routledge.

Maddison, A. (2007). Contours of the world economy 1-2030 AD: Essays in macro-economic history. Oxford University Press.

Maddison, A. (2007). The world economy: A millennial perspective. Academic Foundation.

Maddison, A. (2007). The world economy: Historical statistics. Academic Foundation.

Marichal, C. (1989). A century of debt crises in Latin America: from independence to the Great Depression, 1820-1930. Princeton, NJ: Princeton University Press.

Marichal, C. (2010). Nueva historia de las crisis financieras. Una perspectiva global 1873-2008. Barcelona: Debate, 2010.

Martínez-Galarraga, J., Rosés, J. R., \& Tirado, D. A. (2015). The long-term patterns of regional income inequality in Spain, 1860-2000. Regional Studies, 49(4), 502-517.

McClelland, P. D. (1973). Model-building in the new economic history. American Behavioral Scientist, 16(5), 631-651.

McClelland, P. D. (1975). Causal Explanation and Model Building. Cornell University Press, London.

McCloskey, D. N. (1987). Econometric history. MacMillan Education, Limited.

McCloskey, D. N. (1978). The achievements of the cliometric school. The Journal of Economic History, 38(1), 13-28.

Meyer, J. R. (1955). An input-output approach to evaluating the influence of exports on British industrial production in the late 19th century. Explorations in Economic History, 8(1), 12.

Mejía, J. (2015) Reconstrucción de PIB regionales en Colombia (1800-2015): Una revisión crítica de las fuentes y los métodos. Economía y Sociedad, 30, forthcoming.

Michalopoulos, S., \& Papaioannou, E. (2013). Pre-Colonial Ethnic Institutions and Contemporary African Development. Econometrica, 81(1), 113-152.

Mokyr, J. (2010). On the supposed decline and fall of economic history. Historically Speaking, 11(2), 21-25.

North, D. C. (1974). Beyond the new economic history. The Journal of Economic History, 34(1), 1-7.

North, D. C. (1977). The new economic history after twenty years. The American Behavioral Scientist (pre-1986), 21(2), 187-200.

North, D. C. (1978). Structure and performance: The task of economic history.Journal of Economic literature, 16(3): 963-978.

North, D. C. (1990). Institutions, institutional change and economic performance. Cambridge University Press.

North, D. C., \& Thomas, R. P. (1973). The rise of the western world: A new economic history. Cambridge University Press. 
North, D. C., Wallis, J. J., Webb, S. B., \&Weingast, B. R. (2007). Limited Access Orders in the Developing World: A New Approach to the Problems of Development. Policy Research Working Paper Series 4359, The World Bank.

Nunn, N. (2009). The Importance of History for Economic Development. Annual Review of Economics, 1(1):65-92.

Ober, J. (2015). The Rise and Fall of Classical Greece. Princeton University Press.

Olsson, O., \& Hibbs, D. A. (2005). Biogeography and long-run economic development. European Economic Review, 49(4), 909-938.

Reinhart, C. M., \& Rogoff, K. (2009). This time is different: eight centuries of financial folly. Princeton University Press.

Rodrik, D., Subramanian, A., \& Trebbi, F. (2004). Institutions rule: the primacy of institutions over geography and integration in economic development. Journal of economic growth, 9(2), 131-165.

Rojas, A. M. (2007). Cliometrics: A Market Account of a Scientific Community (1957-2006). Lecturas de Economía, 66, 47-82.

Rosés, J. R., Martínez-Galarraga, J., \& Tirado, D. A. (2010). The upswing of regional income inequality in Spain (1860-1930). Explorations in Economic History, 47(2), 244-257.

Scheiber, H. N. (1967). On the New Economic History: And Its Limitations: A Review Essay. Agricultural History, 41(4), 383-396.

Schulze, M. S. (2007). Regional income dispersion and market potential in the late nineteenth century Hapsburg Empire. Economic History Working. Papers 22311. London School of Economics and Political Science, Department of Economic History, november.

Scheidel, W., Morris, I., \& Saller, R. P. (2007). The Cambridge economic history of the Greco-Roman world. Cambridge: Cambridge University Press.

Shionoya, Y. (2005). The soul of the German historical school: methodological essays on Schmoller, Weber, and Schumpeter. The European heritage in economics and the social sciences. Springer.

Spolaore, E., \& Wacziarg, R. (2013). How Deep Are the Roots of Economic Development? Journal of Economic Literature, 51(2), 325-369.

Tabellini, G. (2010). Culture and institutions: economic development in the regions of Europe. Journal of the European Economic Association, 8(4), 677-716.

Tilly, R. (2001). German economic history and Cliometrics: A selective survey of recent tendencies. European Review of Economic History, 5(2), 151-187.

Turchin, P. (2005). A primer on statistical analysis of dynamical systems in historical social sciences (with a particular emphasis on secular cycles). Structure and Dynamics, 1(1),1-10.

Turchin, P. (2010). Warfare and the evolution of social complexity: A multilevel-selection approach. Structure and Dynamics, 4(3),1-37.

Turchin, P. (2011). Toward Cliodynamics - an Analytical, Predictive Science of History. Cliodynamics, 2(1), 167-186. 
Turchin, P. (2013). The rise and fall of cliometrics, and the coming rise of cliodynamics.

Turchin, P., \& Gavrilets, S. (2009). Evolution of complex hierarchical societies. Social Evolution \& History, 8(2), 167-198.

Turchin, P., Whitehouse, H., Francois, P., Slingerland, E., \& Collard, M. (2012). A historical database of sociocultural evolution. Cliodynamics: The Journal of Theoretical and Mathematical Histo$r y, 3(2), 271-293$.

Van Bavel, B., Campopiano, M., \& Dijkman, J. (2014). Factor markets in early Islamic Iraq, C. 6001100 AD. Journal of the Economic and Social History of the Orient, 57(2), 262-289.

Voigtländer, N., \& Voth, H. J. (2006). Why England? Demographic factors, structural change and physical capital accumulation during the Industrial Revolution. Journal of Economic Growth, 11(4), 319-361.

Voigtländer, N., \& Voth, H. J. (2013). The three horsemen of riches: Plague, war, and urbanization in early modern Europe. The Review of Economic Studies, 80(2), 774-811.

Wallerstein, I. (1974). Capitalist Agriculture and the Origins of the European World Economy. New York: Academic Press.

Whaples, R. (2010). Is Economic History a Neglected Field of Study? Historically Speaking, 11(2), 17-20.

Whitney, W. G. (1968). The structure of the American economy in the late nineteenth century. Harvard University.

Wright, G. (2001). Economic history, quantitative: United States. International Encyclopedia of the Social \& Behavioral Sciences. Elsevier. 